\title{
Production of Seedless Fruits in Hyuganatsu, Citrus tamurana Hort. ex TANAKA, and Hassaku, Citrus hassaku Hayata through Pollination with Pollen Grains from the $4 \times$ Natsudaidai, Citrus natsudaidai HaYATA
}

\author{
Kensuke Yamashita \\ College of Agriculture, Miyazaki University, Miyazaki
}

\begin{abstract}
Summary
1. The present paper deals with the preliminary efforts to produce seedless fruits in Hyuganatsu and Hassaku using crosses of $2 \mathrm{X} \times 4 \mathrm{X}$, a procedure which results in the formation of abortive seeds in many cases.

2. Two hundred flowers of Hyuganatsu(Citrus tamurana Hort. ex TANAKA) were emasculated and pollinated with pollen grains of the $4 \mathrm{X}$ Natsudaidai (Citrus natsudaidai HAYATA). The fruits thus obtained were normal in size, weight and skin color, but almost all the seeds degenerated into rudiments and traces at an early stage of development. They were virtually seedless.

3. The soluble solid and titrable acid contents in the juice of the ripe seedless fruits showed no difference from the control. The edible portion of these fruits increased by $15 \%$ as compared with the control.

4. The seedless fruits did not differ from the controls by date of dropping early or late. Also they displayed similar pattern of development of dry juice sacs after freezing in the winter. The fruits after harvest were stored in a carton box under room condition for about two months. They did not display any particular change in the contents of the soluble solids and titrable acids in the juice during storage. The seedless fruits seemed to soften a little faster than that of the control fruits.

5. The flowers of the Hassaku (Citrus hassaku HAYATA) were pollinated with pollen grains of the $4 \mathrm{X}$ Natsudaidai. The fruits thus obtained were virtually seedless and did not differ from the control in fruit growth and size or in other qualities. The results coincided with those for the Hyuganatsu $\times 4 \mathrm{X}$ Natsudaidai cross.

6. Further investigations are under way for the purpose of finding the proper proportion of the $4 \mathrm{X}$ Natsudaidai tree to be planted as a pollinizer for Hyuganatsu.
\end{abstract}

\section{Introduction}

Hyuganatsu (Citrus tamurana Hort. ex $\mathrm{T}_{\mathrm{A}}$ NAKA) is one of the late citrus varieties which has very good flavor. This is the local variety originated in Miyazaki and is now cultivated in limiting southern areas of Japan on a small scale, because many fruits drop in winter and dry juice sacs develop to a considerable extent after freezing. Since this variety is self-incompatible and non-parthenocarpic, Natsudaidai (Citrus natsudaidai HAYATA) trees are usually mix-planted as a pollinizer(6). An

Received for publication October 2, 1975. average fruit of Hyuganatsu weighs $200 \mathrm{~g}$ at the time of harvest and contains as many as 20 seeds in the center of the fruit, and therefore the edible portion is displaced considerably. The auther is looking for any means possible to produce a seedless fruit.

In 1971, Nakajima dipped some flowers into a $100 \mathrm{ppm} \mathrm{GA}_{3}$ solution at flowering time and succeeded in inducing parthenocarpic fruits(7). In 1972, Yamamoto and Yamashita sprayed a $500 \mathrm{ppm}$ water solution of $\mathrm{GA}_{3}$ onto the flowers of Hyuganatsu at full bloom and succeeded in obtaining seedless fruits, but the fruits were too small for commercial use(10). 
The author's intention to use the $4 \mathrm{X}$ Natsudaidai as a pollinizer was based on the observation that crosses of $2 \mathrm{X} \times 4 \mathrm{X}$ result in the formation of abortive seeds in many cases $(1,5,9)$. In the present experiment, the emasculated flowers of Hyuganatsu were pollinated with pollen grains of the $4 \mathrm{X}$ Natsudaidai, and this procedure succeeded in yielding seedless fruits of normal size. The same experiment was also carried out with Hassaku (Citrus hassaku HAYATA), which, like Hyuganatsu, is a self-incompatible variety.

\section{Materials and Methods}

The $4 \mathrm{X}$ tree of Natsudaidai used in the present experiment was found as a chance seedling by Dr. Furusato some decades ago(5), and has been grown in the orchard of $\mathrm{Mr}$. S. Mizuta in Manazuru, Kanagawa Prefecture.

In April, a branch of the $4 \mathrm{X}$ tree was covered with a vinyl sheet for the purpose of speeding-up the flowering time, and pollen grains were collected a few days before pollination and brought to Miyazaki in a small bottle in which a small volume of silica gel was contained as a desicant. The germination percentage of these pollen grains was $5 \%$ on a $1 \%$ agar medium with $10 \%$ sucrose. The characteristics of floral organs as well as leaves of the $4 \mathrm{X}$ Natsudaidai are shown in Figs. 11 and 12, and Table 4.

At flowering time, 200 emasculated flowers of Hyuganatsu were pollinated with pollen grains of the $4 \mathrm{X}$ Natsudaidai in the experimental orchard of Miyazaki University. As a cantrol, the same number of emasculated flowers were pollinated with pollen grains of the $2 \mathrm{X}$ Natsudaidai. All the flowers were covered after pollination with paper bags for about one week to prevent contamination by foreign pollen grains. The transverse diameter of the fruits was measured every two weeks until harvest. At harvest, several fruit characteristics as given in Figs. 5,6 and 7, and Table 1 were observed for these fruits. Frequencies of fruit drop early in the season as well as during winter were also investigated. Of these harvested fruits, the proprotion of dry juice sac was graded into 5 categories from 0 to 4 (Fig. 10).

In the case of the Hassaku, 30 emasculated flowers were pollinated with pollen grains of the $4 \mathrm{X}$ Natsudaidai and bagged for the following 7 days. Thirty flowers left for open pollination were used for the control. The transverse diameter of the fruits was measured every two weeks until harvest. Several fruit characteristics as given in Figs. 8 and 9, and Table 2 were investigated for the harvested fruits.

\section{Results and Discussion}

\section{Fruit growth and development}

Figs, 1 and 2 show pictures of transverse sections of the seeded and seedless fruits of the Hyuganatsu and Hassaku harvested in September; in each figure, the left is the control and contains many seeds, while the right, being vertually seedless, is the fruit obtained through pollination with pollen grains of the $4 \mathrm{X}$ Natsudaidai. There was almost no difference in fruit size between them. Figs. 3 and 4 show the growth curves showed the

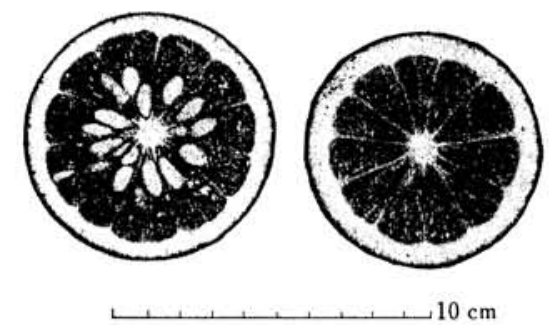

Fig. 1. Transverse sections of seeded and seedless fruits in Hyuganatsu (Photo. Sept. 23, '74) left: Seeded fruit bred by pollination with pollen grains of the $2 \mathrm{X}$ Natsudaidai (control) right : Seedless fruit bred by pollination with pollen grains of the $4 \mathrm{X}$ Natsudaidai
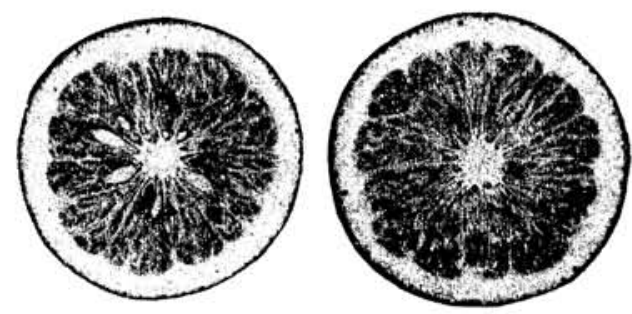
$10 \mathrm{~cm}$

Fig. 2. Transverse sections of seeded and seedless fruits in Hassaku (Photo. Sept. 23. '74) left : Seeded fruit bred by open pollination right : Seedless fruit bred by pollination with pollen grains of the $4 \mathrm{X}$ Natsudaidai 


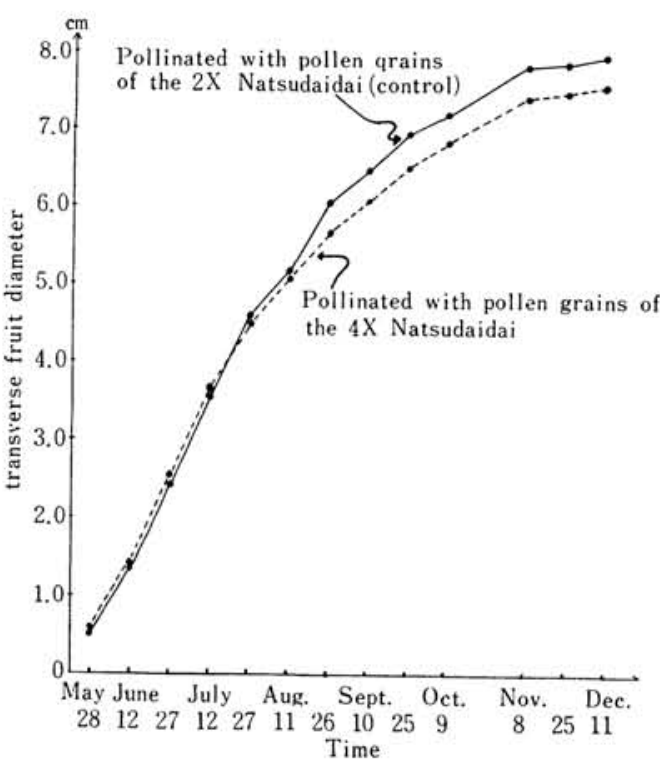

Fig. 3. Growth curves of seeded and seedless fruits in Hyuganatsu bred by pollination with pollen grains of the $2 \mathrm{X}$ and $4 \mathrm{X}$ Natsudaidai (Each value is the average of 30 fruits)

tendency that the seedless fruits were a little larger than the seeded ones from May to July, but the reverse became true after August. In Hassaku, the growth curves showed the tendency that the seedless fruits were observed to be larger than the seeded ones during the whole period of development.

It is said that the growth and development of a fruit is influenced by the function of plant hormones produced in the seeds. In fact, in Hyuganatsu, a high correlation of 0.82 was observed between fruit weight and seed number(10). But in fruits obtained through pollination with pollen grains of the $4 \mathrm{X}$ Natsudaidai, only a few seeds were found together with a large number of undeveloped seeds. The reason why these seedless fruits grew to normal size may be partly due to the hormone stimulus given by pollen grains of the $4 \mathrm{X}$ Natsudaidai, but mostly due to the function of plant hormones which young ovules may have produced until they became abortive. In fact, the author observed that some of the ovules developed into young seeds until August and then degenerated into abortive seeds. It has been clarified, furthermore, that such abortive seeds are formed by the degenera-

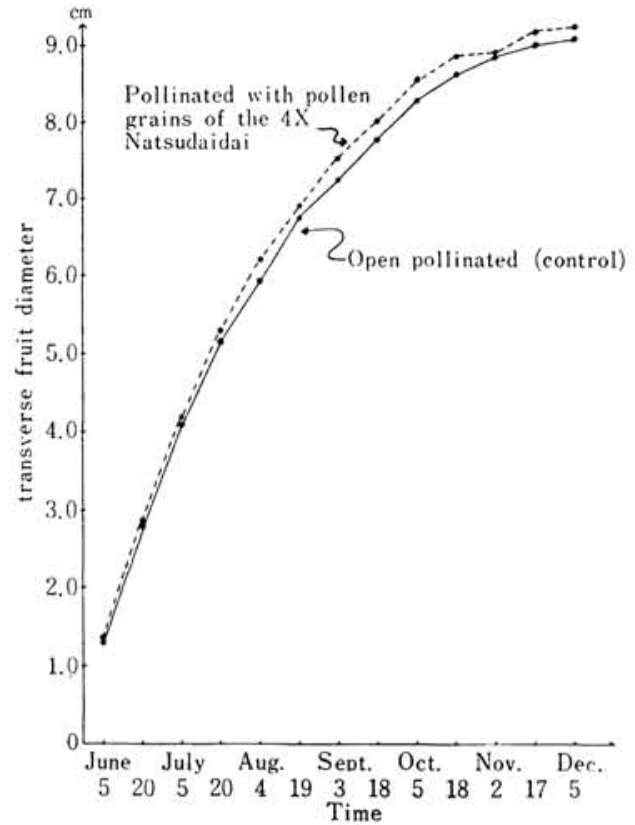

Fig. 4. Growth curves of seeded and seedless fruits in Hassaku bred by pollination in the open and with pollen grains of the $4 \mathrm{X}$ Natsudaidai (Each value is the average of 30 fruits)

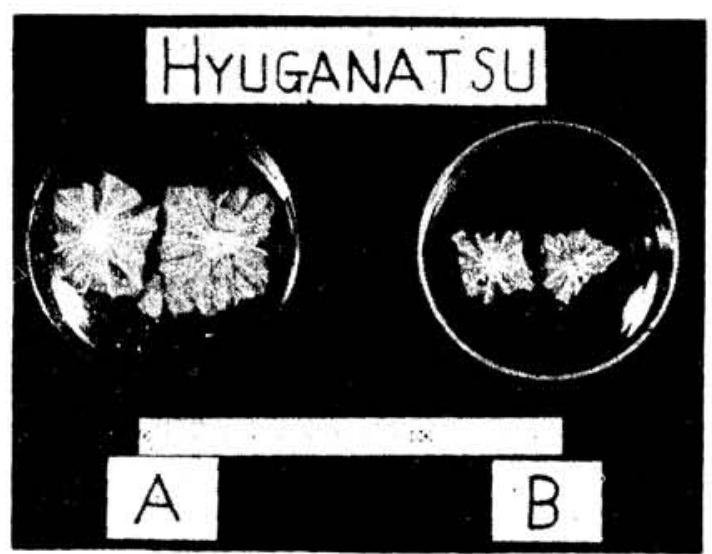

Fig. 7. Seed clusters of seeded and seedless fruits in Hyuganatsu at harvest (Photo. Jan. 13, '75) A : Seeded fruit (control) B : Seedless fruit

tion of the embryo due to the disproportion in the number of chromosomes between embryo and endosperm in their early development $(2,3,4,5)$.

\section{Fruit characteristics at harvast}

The characteristics of the fruits of the Hyuganatsu at harvest are given in Figs. 5, 6 and 7 , and Table 1. Average weight of the seedless and seeded fruit was $189.5 \mathrm{~g}$ and 
Table 1. Characteristics of seeded and seedless fruits in Hyuganatsu bred by pollination with pollen grains of the $2 \mathrm{X}$ and $4 \mathrm{X}$ Natsudaidai (Investigated on Jan. 13, 1975*)

\begin{tabular}{|c|c|c|c|c|c|c|c|c|c|c|}
\hline \multirow{3}{*}{$\begin{array}{l}\text { Pollen } \\
\text { source }\end{array}$} & \multirow{3}{*}{$\begin{array}{c}\text { Fruit } \\
\text { weight } \\
(\mathrm{g})\end{array}$} & \multirow{3}{*}{$\begin{array}{l}\text { Fruit } \\
\text { width } \\
(\mathrm{mm}) \\
\end{array}$} & \multirow{3}{*}{$\begin{array}{l}\text { Fruit } \\
\text { length } \\
(\mathrm{mm})\end{array}$} & \multirow{3}{*}{$\begin{array}{l}\text { Weight of } \\
\text { edible } \\
\text { portion } \\
\text { (g) }\end{array}$} & \multirow{3}{*}{$\begin{array}{c}\begin{array}{c}\text { Soluble } \\
\text { solid }\end{array} \\
\text { (Brix) }\end{array}$} & \multirow{3}{*}{$\begin{array}{c}\text { Citric } \\
\text { acid } \\
(\mathrm{g} / 100 \mathrm{cc})\end{array}$} & \multirow{3}{*}{$\begin{array}{c}\text { Number } \\
\text { of perfect } \\
\text { seed }\end{array}$} & \multirow{2}{*}{\multicolumn{3}{|c|}{ Number of imperfect seed }} \\
\hline & & & & & & & & & & \\
\hline & & & & & & & & $\begin{array}{c}0 \sim 3 \\
(\mathrm{~mm})\end{array}$ & $\begin{array}{c}3 \sim 7 \\
(\mathrm{~mm})\end{array}$ & $\begin{array}{l}7 \sim \\
(\mathrm{mm})\end{array}$ \\
\hline $4 X$ & $189.4 \pm 11.9$ & $78.5 \pm 3.4$ & $71.0 \pm 2.0$ & $134.8 \pm 11.7$ & $10.3 \pm 0.6$ & $2.05 \pm 1.06$ & 1.25 & 20.8 & 2.3 & 25.6 \\
\hline $2 X$ & $195.4 \pm 18.7$ & $78.6 \pm 3.3$ & $70.0 \pm 3.6$ & $112.4 \pm 11.0$ & $10.3 \pm 0.8$ & $2.08 \pm 0.36$ & 33.0 & 10.7 & 5.9 & 1.9 \\
\hline
\end{tabular}

* ...Each value is the average of 20 fruits

Table 2. Characteristics of seeded and seedless fruits in Hassaku bred by pollination in the open and with pollen grains of the $4 \mathrm{X}$ Natsudaidai (Investigated on Jan. 13, 1975*)

\begin{tabular}{|c|c|c|c|c|c|c|c|c|c|c|}
\hline \multirow{3}{*}{$\begin{array}{l}\text { Pollen } \\
\text { source }\end{array}$} & \multirow{3}{*}{$\begin{array}{c}\text { Fruit } \\
\text { weight } \\
(\mathrm{g})\end{array}$} & \multirow{3}{*}{$\begin{array}{l}\text { Fruit } \\
\text { width } \\
(\mathrm{mm})\end{array}$} & \multirow{3}{*}{$\begin{array}{r}\text { Fruit } \\
\text { length } \\
(\mathrm{mm})\end{array}$} & \multirow{3}{*}{$\begin{array}{c}\begin{array}{c}\text { Flesh } \\
\text { weight }\end{array} \\
\text { (g) }\end{array}$} & \multirow{3}{*}{$\begin{array}{c}\begin{array}{c}\text { Soluble } \\
\text { solid }\end{array} \\
\text { (Brix) }\end{array}$} & \multirow{3}{*}{ 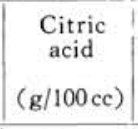 } & \multirow{3}{*}{$\begin{array}{c}\text { Number } \\
\text { of perfect } \\
\text { seed }\end{array}$} & \multirow{2}{*}{\multicolumn{3}{|c|}{$\frac{\text { Number of imperfect seed }}{\text { length }}$}} \\
\hline & & & & & & & & & & \\
\hline & & & & & & & & $\begin{array}{c}0 \sim 3 \\
(\mathrm{~mm})\end{array}$ & $\begin{array}{c}3 \sim 7 \\
(\mathrm{~mm})\end{array}$ & $\begin{array}{l}7 \sim \\
(\mathrm{mm})\end{array}$ \\
\hline $4 X$ & $327.0 \pm 61.0$ & $93.0 \pm 6.8$ & $76.0 \pm 6.3$ & $215.0 \pm 35.8$ & $9.0 \pm 0.5$ & $|1.50 \pm 0,13|$ & 0,35 & 37.5 & 5.2 & 13,3 \\
\hline $2 X$ & $312.5 \pm 69.2$ & $92.0 \pm 9.6$ & $74.3 \pm 7.1$ & $214.2 \pm 48.0$ & $9.0 \pm 0.6$ & $1.50 \pm 0.10$ & 8.55 & 35.9 & 0.8 & 1.9 \\
\hline
\end{tabular}

$195.4 \mathrm{~g}$, respectively. Concerning pericarp color, there was no difference between the seedless fruits and the seeded ones, but the flesh color of the former was citron yellow while the latter was dirty yellow. The content of soluble solids and titrable acids in the juice were nearly the same.

In the Hyuganatsu, the edible portion was considerably reduced because of the large cluster of seeds; as many as 30 seeds per fruit were formed in the control in the present experiment. Subsequently, the edible portion of the seedless fruit was increased by $15 \%$ as compared with that of the control.

The results obtained in the Hassaku are given in Figs. 8 and 9, and Table 2. The seedless fruits contained only a few perfect seeds and the edible portion increased as compared with the control.

3. Fruit drop, development of dry juice sac and change of fruit quality during storage

The number of fruit dropped early was counted on September 10 th. It was 48 for the control, while it was 58 for the case of pollination with pollen grains of the $4 \mathrm{X}$ Natsudaidai.

On March 12 th, the number of remaining fruits was counted. It was 121 in the former, and 111 for the latter. The result corresponds to that of Miwa in that there was no difference between the late drop and seed number in the Hyuganatsu(5).
Table 3. Change of fruit quality during storage in Hyuganatsu

\begin{tabular}{l|c|c|r|c}
\hline & $\begin{array}{c}\text { Pollen } \\
\text { source }\end{array}$ & Mar. 14 & Apr. 14 & May 24 \\
\hline Soluble solid & $4 \mathrm{X}$ & 9.95 & 9.90 & 10.30 \\
(Brix) & $2 \mathrm{X}$ & 10.54 & 10.20 & 10.80 \\
Citric acid & $4 \mathrm{X}$ & 1.96 & 2.30 & 2.21 \\
(g/100 cc) & $2 \mathrm{X}$ & 1.67 & 2.40 & 2.05 \\
Grade of dry & $4 \mathrm{X}$ & 0 & 0.9 & 1.2 \\
juice sac* & $2 \mathrm{X}$ & 0.7 & 0.8 & 0.9 \\
Skin hardiness & $4 \mathrm{X}$ & 3.02 & 2.77 & - \\
(kg) & $2 \mathrm{X}$ & 3.35 & 3.07 & - \\
\hline
\end{tabular}

*...Grade is shown in Fig. 10

As to development of dry juice sacs after freezing in winter, there seemed to be no difference between the seeded fruits and seedless ones. According to Nakajima, this defect occurred more frequently in the smaller fruits outside the canopy than in the larger fruits inside the canopy; the symptoms of the disorder were much more severe in the seedy segments on the sunscald side than in those on the healthy side of the fruits(8).

About the change of the soluble solid and titrable acid contents in the juice during storage, no peculiarity was found in the seedless fruits.

4. Further considerations for the practical application of the $4 \mathrm{X}$ Natsudaidai as a pollinizer

Concerning mix-planting of the $4 \mathrm{X}$ Natsudaidai tree as a pollinizer for Hyuganatsu, the following points are left for further 


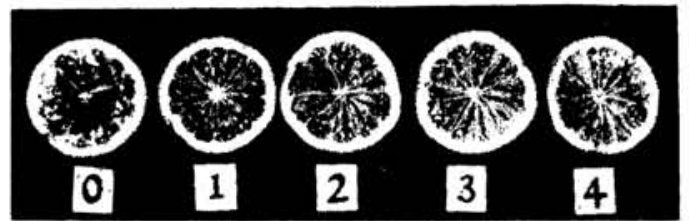

Fig. 10. Grade of dry juice sac after freezing in Hyuganatsu fruit (Photo. April 14, '75)

Table 4. Characteristics of floral organs and leaves of the $4 \mathrm{X}$ Natsudaidai in comparison with those of the $2 X$ Natsudaidai

\begin{tabular}{lc|c|c} 
& & \multicolumn{2}{|c}{ Pollen source } \\
\cline { 3 - 4 } & & $2 \mathrm{X}$ & $4 \mathrm{X}$ \\
\hline Petal length & $(\mathrm{mm})$ & 17.7 & 17.9 \\
Petal width & $(\mathrm{mm})$ & 7.6 & 9.3 \\
Number of stamen & 27.95 & 31.25 \\
Pistil length & $(\mathrm{mm})$ & 13.3 & 10.7 \\
Ovary weight & $(\mathrm{g})$ & 1.22 & 1.57 \\
Leaf length & $(\mathrm{mm})$ & 11.25 & 11.59 \\
Leaf width & $(\mathrm{mm})$ & 4.38 & 5.55 \\
\hline
\end{tabular}

Each value is the average of 20 flowers and leaves

\section{consideration.}

Presently, Natsudaidai or Hassaku is mixplanted as a pollinizer in a proportion from $10 \%$ to $15 \%$. There is some question whether this proportion is proper for the $4 \mathrm{X}$ Natsudaidai as a pollinizer since the quantity of pollen grains of a tetraploid is generally less than that for a diploid. But, the $4 \mathrm{X}$ Natsudaidai used in the present experiment did not differ from the $2 \mathrm{X}$ Natsudaidai in both the quantity of pollen grains per flower and the numder of flowers per unit shoot length. Furthermore, the pollen fertility of the former did not differ from the latter so far as could be observed by the acetocarmine and cotton blue staining methods. The proper proportion of the $4 \mathrm{X}$ Natsudaidai to be planted as a pollinizer for Hyuganatsu will be found through further in vestigations.

According to Dr. Furusato, the fruit of the $4 \mathrm{X}$ Natsudaidai was a little smaller than that of the $2 \mathrm{X}$ Natsudaidai; its flesh was slightly less voluminous than that of the $2 \mathrm{X}$ Natsudaidai because of its thick pericarp ; its flesh was less juicy and a little harder than that of the $2 \mathrm{X}$ Natsudaidai. Since the fruit quality of the $4 \mathrm{X}$ Natsudaidai seems to be a little inferior to that of the $2 \mathrm{X}$ Natsudaidai, it is assumed that the retail value of the $4 \mathrm{X}$ Natsudaidai will be lower than that of the $2 \mathrm{X}$ Natsudaidai. But, if the sedless Hyuganatsu compensates the loss, it could be sufficiently profitable on a commercial scale.

There are some problems to be solved before practical application, but the results of the present experiment indicates the possibility of using the $4 \mathrm{X}$ Natsudaidai as a pollinizer in the practical production of seedless fruits in Hyuganatsu and Hassaku.

\section{Acknowledgement}

The author wishes to express his deep gratitude to Dr. Kazuo Furusato, Director of Hamamatsu Flower Park, for his suggestions throughout the course of this study. The author is greatly indebted to Mr. Susumu Mizuta for his kindness in giving me access to his invaluable $4 \mathrm{X}$ Natsudaidai. The autho wishes to express whole-hearted thanks to Dr. Akira Kobayashi, President of Agricultural Junior College in Ishikawa Prefecture, for his kind advice and constant encouragement. The author is very grateful to Dr. Takashi Tomana, Professor of Kyoto University, for his invaluable guidance and suggestions throughout the course of this study. The author wishes to thank to Dr. Kiyoshi Gomi, Professor of Miyazaki University, for his constant encouragement.

\section{Literature Cited}

1. Cameron, J.W. and R.K.Soost. 1969. Characters of new populations of Citrus polyploids, and the relation between tetraploidy in the pollen parent and hybrid tetraploid progeny. Proc. 1st Int. Citrus Symp. 1:199-205.

2. ESEN, A. and R. K. SoosT. 1971. Unexpected triploid in Citrus : their origin, identification, and possible use. J. Hered. $62: 329-333$.

3. — and 1972. Tetraploid progenies from $2 \mathrm{X} \times 4 \mathrm{X}$ crosses of Citrus and their origin. J. Amer. Soc. Hort. Sci. $97:$ 410-414.

4. - Relation of unexpected polyploids to diploid megagametophytes and embryo: endosperm ploidy ratios in Citrus. Abstract. of Proc. 1973. Int. Citrus Cong.

5. FURUSATO, K. 1961. Studies on cytoplasmic inheritance and polyembryony in Citrus. Doctral Thesis at Kyoto Univ.

6. MiWA, T. 1951. Pollination, fertilization, and fruit drop in Citrus tamurana Hort. Bull. Miyazaki Univ. (Natural Science) $2: 1-67$.

7. NaKaJima, Y. 1973. Studies on the fruit 
development and physical disorders in the late sta ges of development of Hyuganatsu (Citrus tamurana Hort.) in Kochi. Mem. Fac. Agr., Kochi Univ. 22 : 1-53.

8. —, T. MiYAmoto, Y. ANDO, and K. SHINKAI. 1974. Studies on dry juice sac of Hyuganatsu (Citrus tamurana Hort.) occurred by freezing. Res. Rep. Kochi Univ. $23: 147-$ 153.
9. TACHIKAWA, T., Y. TANAKA, and S. HARA. 1961. Investigations on the breeding of Citrus trees. 1. Study on the breeding of triploid Citrus varieties. Shizuoka Pref. Citrus Exp. Sta. $4: 33-44$.

10. YамAMOTO, S. and K. YAMASHitA, Jr. 1972. Parthenocarpy of Hyuganatsu (preliminary Report) Induction of parthenocarpy by $\mathrm{GA}_{3}$. Agr. and Hort. $47: 635-636$.

\section{4 倍体ナツダイダイ花粉の受粉による無種子のヒューガナツ およびハッサク果実の生産}

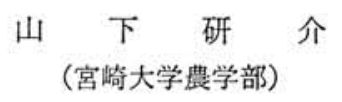

\footnotetext{
摘 要

4 倍体ナッダイダイを授粉樹としてヒューガナッなら びにハッサクの無種子果を生産する方法について, 実用 化の可能性を探るために本実験を行なった.

1. ヒューガナッの成木を材料として, 開花洔に除雄・ 袋かけを行って 4 倍体ナツダイダイの花粉を人工授粉し た.このようにして得られた果実は, 果実発育の初期に 種子が完全に退化して無種子果となったが, 早期落果・ 後期落果の程度は対照区 ( 2 倍体ナシダイダイ花粉授 粉）とほとんど変わらなかった. 収穫時にこの無種子果 の形質を調査したところ, 果径, 果重, 着色度, 果汁中 の可溶性固形物含量ならびに滴定酸含量, 凍害スフガリ の発生程度については, 対照区との間にほとんど差がみ

られず, 可食部が $15 \%$ も增加した。つぎに収檴果をダ ンポール箱にいれて室温下におき, 眝蔵中の果実の形質 の変化を 2 ケ月間にわたって調査した. その結果, 果汁 中の可溶性固形物含量ならびに滴定酸含量の変化, スア ガリの進行については, 対照区との間に差はみられなか ったが，果皮の軟化はやや早い上うに観察された.

2. 八ッサク若木を材料として, 開花時に除雄・袋か けを行って倍体ナッダイダイの花粉を人工授粉した. 得 られた無種子果の肥大発育ならびに収檴時の形質は対照 区（放任受粉）と比べてほとんど差がなかった.

なお授粉樹としての 4 倍体ナッダイダイの適正混植率 について検討を加えるため実験を継続中である.
} 


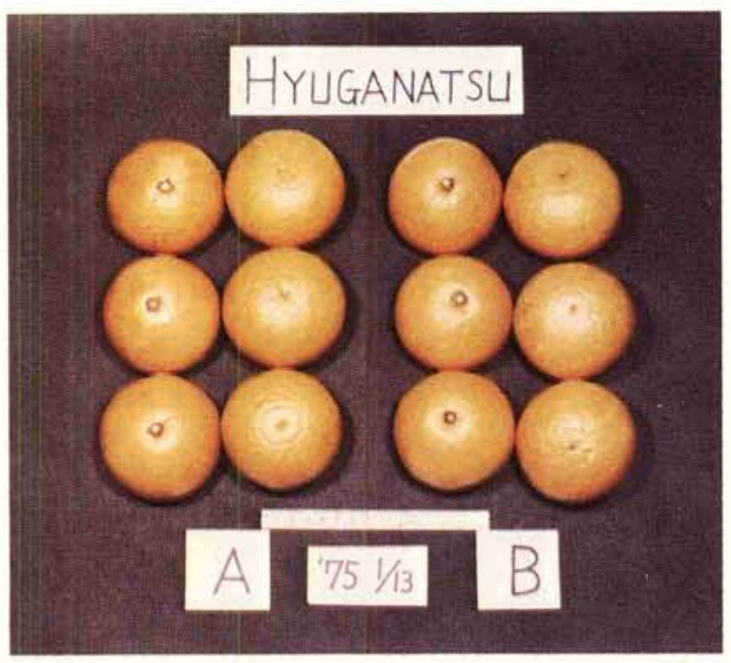

Fig. 5. Appearance of seeded and seedless fruits in Hyuganatsu (Photo. Jan. 13, '75)

A : Seeded fruit (control) B : Seedless fruit

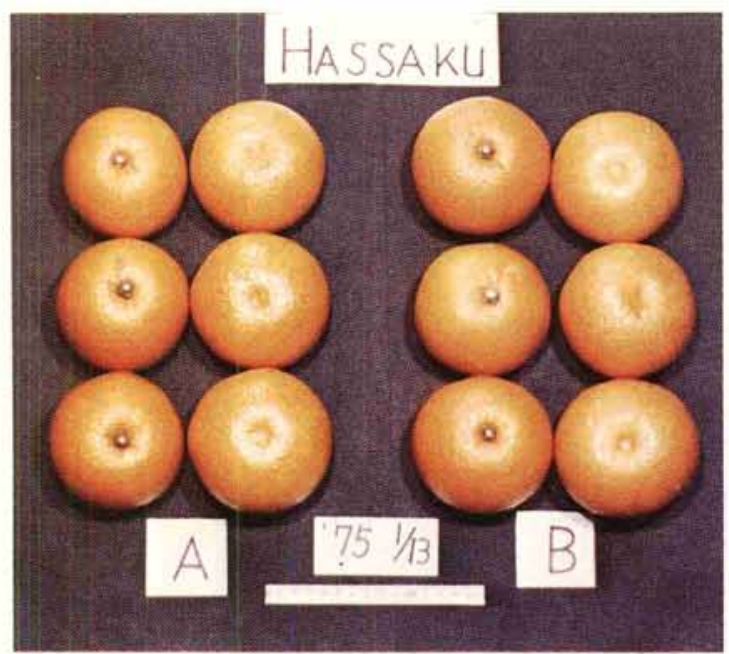

Fig. 8. Appearance of seeded and seedless fruits in Hassaku at harvest (Photo. Jan. 13, '75) A : Seeded fruit (control) B : Seedless fruit

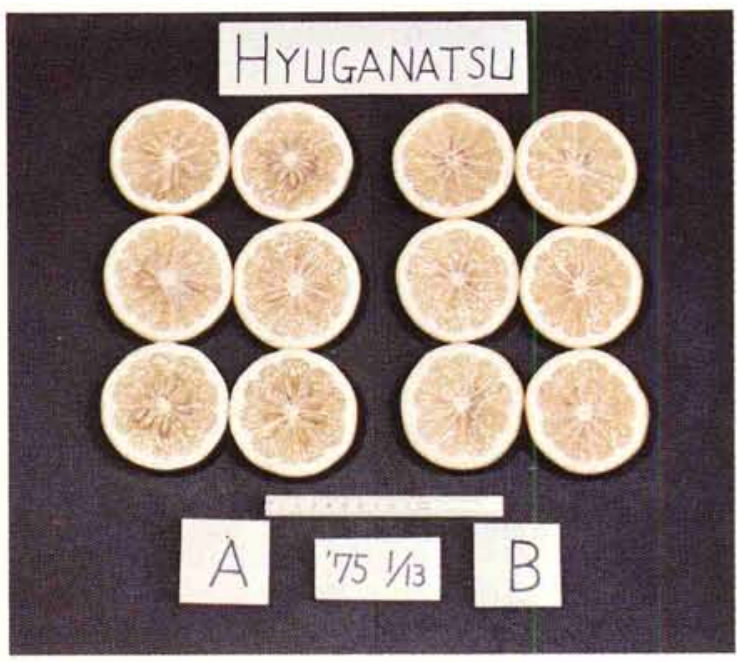

Fig. 6. Transverse sections of seeded and seedless fruits in Hyuganatsu at harvest (Photo. Jan. $13, ' 75)$

A : Seeded fruit (control) B : Seedless fruit

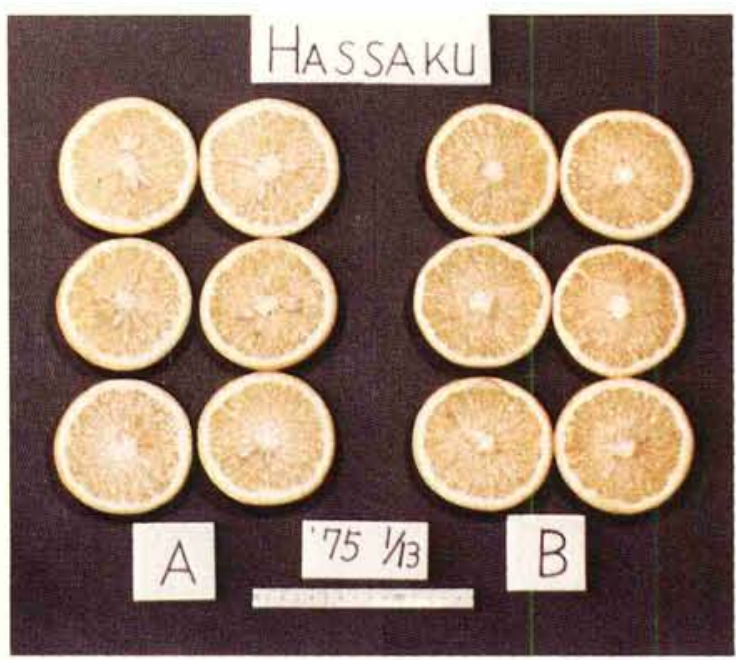

Fig. 9. Transverse sections of seeded and seedless fruits in Hassaku at harvest (Photo. Jan. 13, '75)

A : Seeded fruit (control) B : Seedless fruit 

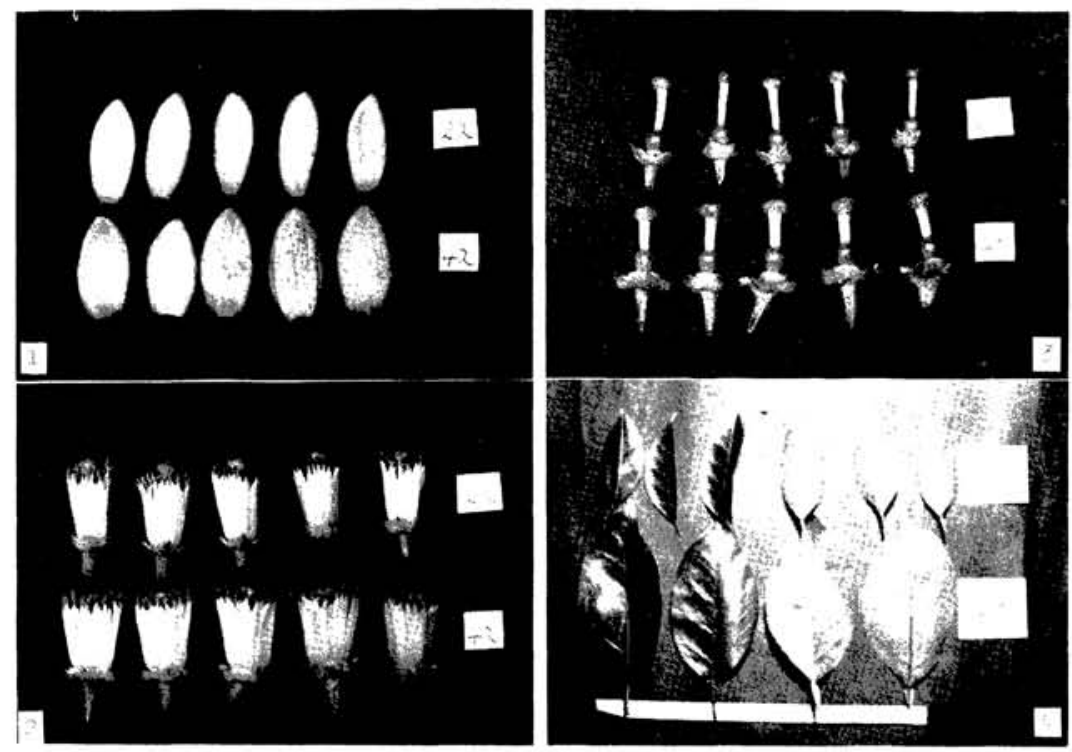

Fig. 11. Floral organs and leaves of the $4 \mathrm{X}$ Natsudaidai as compared with those of the $2 \mathrm{X}$ Natsudaidai 1: Petal 2: Stamen 3:Pistil 4: Leaf

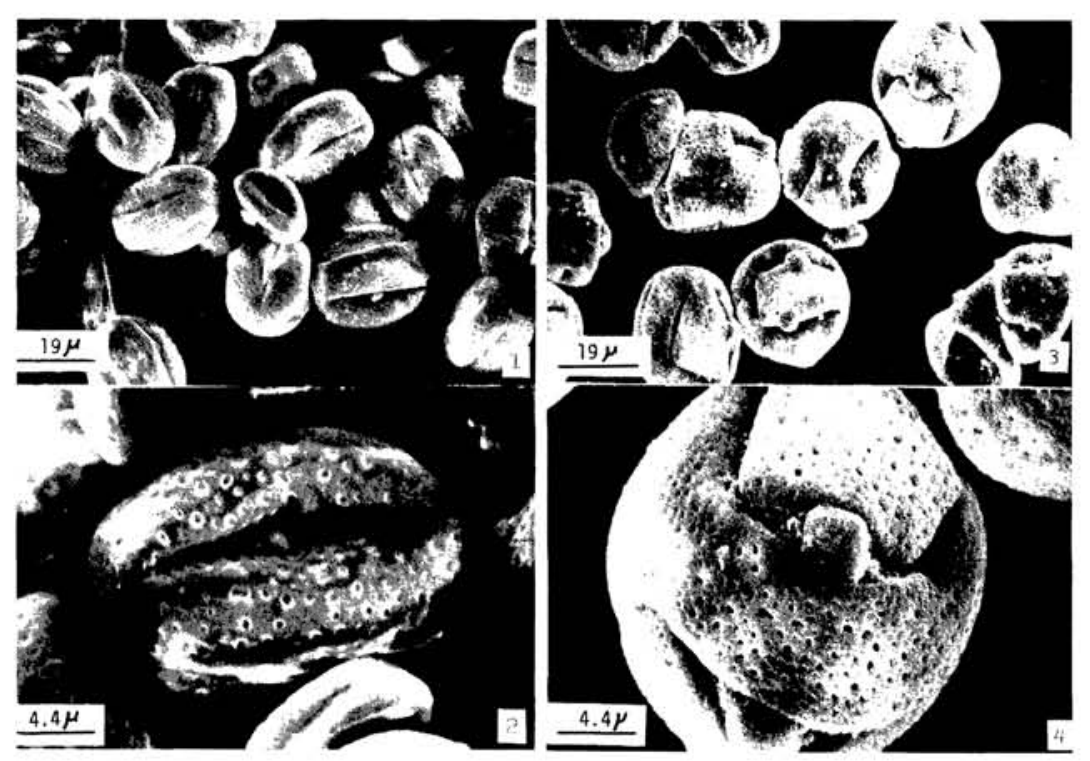

Fig. 12. Pollen grains of the $4 \mathrm{X}$ Natsudaidai observed by a scanning electron microscope 1: Pollen grains of the $2 \mathrm{X}$ Natsudaidai $(\times 1000) 2$ : ditto $(\times 3000) 3:$ Pollen grains of the $4 \mathrm{X}$ Natsudaidai $(\times 1000) 4:$ ditto. $(\times 3000)$ 